Article

\title{
From the Great Recession to the COVID-19 Pandemic: The Risk of Expansionary Monetary Policies
}

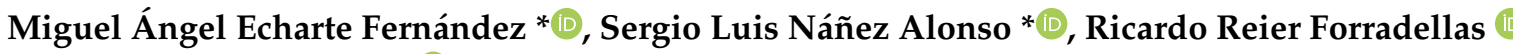 \\ and Javier Jorge-Vázquez (i)
}

check for

updates

Citation: Echarte Fernández, Miguel Ángel, Sergio Luis Náñez Alonso, Ricardo Reier Forradellas, and Javier Jorge-Vázquez. 2022. From the Great Recession to the COVID-19

Pandemic: The Risk of Expansionary Monetary Policies. Risks 10: 23. https://doi.org/ $10.3390 /$ risks 10020023

Academic Editor: Stelios Markoulis

Received: 2 December 2021

Accepted: 13 January 2022

Published: 18 January 2022

Publisher's Note: MDPI stays neutral with regard to jurisdictional claims in published maps and institutional affiliations.

Copyright: (C) 2022 by the authors. Licensee MDPI, Basel, Switzerland. This article is an open access article distributed under the terms and conditions of the Creative Commons Attribution (CC BY) license (https:// creativecommons.org/licenses/by/ $4.0 /)$.
DEKIS Research Group, Department of Economics, Catholic University of Ávila, 05005 Ávila, Spain; ricardo.reier@ucavila.es (R.R.F.); javier.jorge@ucavila.es (J.J.-V.)

* Correspondence: mangel.echarte@ucavila.es (M.Á.E.F.); sergio.nanez@ucavila.es (S.L.N.A.)

\begin{abstract}
Central banks have been pursuing an expansionary monetary policy since before the pandemic, although the health and economic crisis of COVID-19 has boosted asset purchase programmes. After the Great Recession, a new phase began, characterised by low interest rates and liquidity injections. These policies spilled over into financial markets and are leading to higher inflation. These policies stabilised the situation in the short term, but if they continue indefinitely there is a risk of debt overhang, investment mistakes and high inflation in the future. The aim of this article is to analyse monetary policy developments from the Great Recession to the COVID-19 crisis. Correlations between different macroeconomic variables will be shown through IBM SPSS Statistics. For this purpose, bi-variate correlations were used. For the predictions and confidence of the model data, Tableau Desktop Edition was used, which in turn was used for the generation of the graphs. There is a strong correlation between the growth of monetary aggregates and public debt and stock market capitalisation for the selected indicators. The main contribution of this research is the analysis of the long-term effects of a monetary policy.
\end{abstract}

Keywords: expansionary policy; monetary stimulus; negative interest rates; centralized virtual currencies; balance sheet expansion

\section{Introduction}

The aim of this article is to analyse the central bank monetary policy from the years following the Great Recession to the economic crisis generated by the COVID-19 pandemic. The impact of these crises has implied an increase in public borrowing in many countries to cope with rising government expenditures aimed at boosting economic recovery. In general, the financing of this debt has fallen on the central banks of the respective currency areas, which have adopted lax monetary policies consisting of low interest rates (Rogoff 2017; Wang 2018; Echarte Fernández et al. 2021) and the purchase of these securities, expanding their balance sheets and increasing liquidity. For many years this monetary expansion was not passed on to the price of final goods and services but it had an impact on financial markets (bonds and stocks) and possibly on the price of certain safe haven assets such as decentralised cryptocurrencies and gold.

To a large extent, the increase in money supply has been sterilised by a parallel increase in the demand for money as a consequence of the economic uncertainty inherent in times of crisis and the reduced opportunity cost of holding high cash balances in such a low interest rate environment. Some governments issued debt at negative rates as many investors prefer to buy creditworthy government securities, even if they must pay for them, rather than invest in high-risk assets. Negative rates subsidise borrowing and discourage long-term saving (Fukuda 2018; Murota 2019). It is true that expansionary policies have stabilised the situation in the short term after events such as the Great Recession or the pandemic, but if maintained indefinitely they can generate imbalances and risks such as the return of 
inflation in developed countries, public over-indebtedness and massive investment errors in the financial markets through a process of unsustainable growth (boom) that ends in a crisis (bust) (Switzer and Picard 2016; Kaczmarek et al. 2021).

The COVID-19 pandemic emerged in Wuhan (Hubei-China) at the end of 2019 and quickly spread to the rest of the world, causing a health and economic crisis. Although the origin of this crisis is different from that of the 2008 international financial crisis, the response of governments and central banks was in many ways similar. The origin of the Great Recession lies in the previous credit expansion that allowed the financing of many investment projects without a real savings base, which generated overinvestment in the real estate sector through a bubble that eventually collapsed (Alonso Neira et al. 2010; De Soto 2012). This credit expansion was based on the reduction in interest rates, especially from 2002 onwards, by the Federal Reserve (Fed) and the European Central Bank (ECB). Monetary expansion was passed on to the real economy through commercial banks. The COVID-19 crisis is an exogenous crisis and does not have a monetary origin. Indeed, in the years leading up to the pandemic, interest rates were still low, but credit expansion was not taking place partly because banks were more cautious in granting financing and also because economic agents either had the memory of the previous crisis or could not find profitable investment projects in the market. Although the cause of the crisis is different, the reaction of central banks was similar in that they continued monetary stimulus by reinforcing these policies with new programmes or measures (Espinosa et al. 2021)

After the Great Recession, the Fed initiated Quantitative Easing (QE) programmes of which several editions have been approved. This consists of buying assets in secondary markets to inject liquidity into the economy and avoid the bankruptcy of many companies and a federal debt crisis (Nidhiprabha 2016). It is true that the Fed has more room than other central banks to increase the money supply without sharply depreciating its currency because the dollar is the international reserve currency and the main means of payment in global trade. However, as with the policies of other central banks, the question arises as to whether these measures, rather than contributing to long-term economic recovery, do not slow it down or slow it down in the sense that they make it more difficult or prevent governments from adopting structural reforms because they have an easy mechanism to finance deficits and indebtedness. During the pandemic, the Fed took further steps to address the situation. In March 2020, it lowered benchmark interest rates and continued asset purchases and lending to banks. In August of that year the monetary policy target was changed and made more flexible. Thus, instead of aiming for the Consumer Price Index (CPI) not to exceed $2 \%$ per annum, the aim is for it not to do so over an average number of years, so that for a period it will be allowed to be above this limit if it is then compensated for in subsequent years.

The ECB adopted unconventional measures after the Great Recession (Momirovic 2014). A programme of long-term loans to credit institutions was launched through the Targeted Longer-Term Refinancing Operations (TLTROs) and the Long-Term Refinancing Operation (LTRO). The aim of the first of these mechanisms is to encourage banks to grant loans to economic agents because, depending on the volume they lend, they will be able to obtain cheaper financing from the ECB. In fact, banks are penalised for making deposits with the central bank at a rate of $0.5 \%$. The ECB's expansionary policy received a big boost in 2012 when Mario Draghi, then president of the institution, assured that everything possible would be performed to save the euro project in a context of sovereign debt crisis in several eurozone countries. An example of this is Spain, which had a public deficit of $10 \%$ of GDP and the risk premium was at an all-time high. When the COVID-19 health and economic crisis began to affect the European continent, new measures were considered. The ECB improved the conditions of the TLTRO, now in its third edition, and in April 2020 it created the Pandemic Emergency Longer-Term Refinancing Operations (PELTROs), a measure to maintain liquidity injections. A month earlier, the Pandemic Emergency Purchase Programme (PEPP) was approved with an initial endowment of 750 billion, which was subsequently extended. This programme consists of buying assets 
(public and corporate debt) in the secondary markets. The ECB's objective is that inflation, as measured by the harmonised CPI, should not exceed $2 \%$, although it aims for it to be close to that value.

Unlike the Fed, which has a mixed objective (controlling inflation and promoting economic growth), the ECB's sole mission is to monitor price stability. The harmonised CPI for the eurozone was at negative rates (price deflation) at the end of 2020, which provided more room for the ECB's expansionary policies, but already in January 2021 it reached $0.9 \%$. In Germany it reached $1.4 \%$ and the Bundesbank has already warned of the risk of inflation and the need to raise interest rates even at the cost of increasing the financial cost of public debt. By the end of 2021, CPI data surpassed 6\% in the US and stands at $5 \%$ for the Eurozone. The component that has risen the most is energy, a highly regulated sector that has been affected by the costs of the ecological transition that many countries have developed (Wang et al. 2021). Although it is true that after the period of confinement, activity was reactivated and there have been many bottlenecks in international trade, the increase in prices is due to the fact that aggregate demand exceeds aggregate supply because of the fiscal and monetary stimulus policies we are analysing.

At the EU level, the European Union (EU) reached a historic agreement in July 2020 when a 750 billion recovery plan was approved. The fund will be divided among member states and consists of concessional loans and non-repayable grants. Prior to the agreement, the issuance of coronabonds was proposed, a debt mutualisation mechanism that did not go ahead due to opposition from some countries and which had already been proposed after the 2008 crisis under the name of Eurobonds (Sambira 2014). Although formally different, the agreement reached is similar in practice.

In Asia, the reaction to the Great Recession was similar. In 2012 the Bank of Japan (BOJ) approved the "Abenomics" programme, named after Shinzō Abe, who was prime minister of the country until 2020 (Solís and Urata 2018; Ito et al. 2018). Although Japan is a developed and prosperous country, it has been in a phase of economic stagnation for decades despite fiscal and monetary stimuli. In fact, the term "Japanisation" of an economy refers to this situation (Kawai and Morgan 2013). Japan is currently the country with the highest stock of public debt/GDP and the BOJ maintains a negative interest rate. In China, the People's Bank of China (PBOC) pursued a policy of devaluing the local currency, the Yuan, to encourage exports in an environment of currency wars with other powers (Lakdawala 2016; Wang and García 2020).

The crisis generated by the pandemic is increasing the stock of public debt for many governments. In this situation, the possibility of cancelling the debt issued during the health crisis was raised. The first to propose this was an Italian government advisor, but later a communiqué from academics, led by Thomas Piketty and politicians, was released. The ECB rejected it because it would depreciate the assets on its balance sheet and the common currency. Over-indebtedness can generate a sovereign debt problem and a risk of default (Bagus and Howden 2015; Okano and Eguchi 2020).

In recent years, there have been a number of major innovations and transformations in the monetary and financial sphere. On the one hand, the rise of digital payment platforms or means of payment in certain countries has, along with other causes, led to a reduction in the use of cash (Obinabo 2017; Fabris 2019). In Sweden, a large part of the population uses the Swish system and in China, mobile apps such as Alipay or Wechatpay are very successful. Moreover, during the Great Recession, Bitcoin appeared, a decentralised and private cryptocurrency based on Blockchain technology that cannot be regulated or controlled by governments (Ammous 2018; Cachanosky, 2019; Sanz Bas 2020; Sanz Bas et al. 2021). Since then, many such cryptocurrencies have emerged (Ripple, Litecoin, Ethereum, etc.).

In 2019 Facebook announced the creation of Libra, a cryptocurrency backed by a basket of currencies (stablecoin) given that the main problem with the aforementioned currencies is their high volatility. In spite of this, Bitcoin is starting to be in greater monetary demand. At the beginning of 2021, for example, the Miami City Council (Florida-USA) announced the possibility of paying part of the salaries of civil servants and local taxes 
in this cryptocurrency. In June 2021, the Legislative Assembly of El Salvador passed the bitcoin law, granting legal tender status to this cryptocurrency and allowing for a bimonetary system (the dollar, which was adopted in 2001, and bitcoin coexist). Obviously, the emergence of these decentralised virtual currencies can restrict the monetary policy of central banks, which is why some governments have tried, without much success, to ban or regulate them. In the case of China, after years of partial bans on the use of these digital assets, all types of private cryptocurrency transactions have finally been banned (Náñez Alonso et al. 2021a). To address this competition, many central banks are considering issuing their own centralised virtual currencies, known as Central Bank Digital Currencies (CBDCs). In some cases, these currencies may use Blockchain technology itself, but this is not essential.

The rationale for this research lies in the importance of monetary policy as a mechanism for solving specific economic problems in times of crisis and the risks that can arise if monetary expansion continues indefinitely. These risks include excessive public indebtedness, the disincentive for many governments to make structural reforms if they have the backing of the central bank, and the possibility of generating asset bubbles in financial markets.

The methodology of the study consists of carrying out bi-variate correlations to analyse the relationship between different macroeconomic variables and a series of forecasts for various currency areas (US, Eurozone and Japan) using different computer programs. These currency areas were chosen because they represent geographically dispersed areas of high geopolitical importance and their inhabitants are among the highest per capita income earners in the world.

The structure of the article is as follows. After this introduction, the academic literature on these issues will be reviewed and the methodology employed will be presented, using correlations between different macroeconomic variables to analyse the relationship between them over a significant period of time (2012-2020). The empirical results obtained will then be presented and compared with those of other studies. Finally, a series of research conclusions will be drawn, pointing out the main limitations of the study.

The academic literature on the reaction of central banks to the Great Recession is abundant (Bagus and Howden 2009; Bagus and Schiml 2010; Guerello 2018; Guerini et al. 2018; Rogoff 2017; Kenourgios et al. 2019; Tercero-Lucas 2021). The first two studies analyse the monetary policy of the Fed and the ECB during the 2008 crisis. Guerello (2018) studied conventional and unconventional monetary policies in the Eurozone and relates it to income distribution. Guerini et al. (2018) analysed the unconventional policies that were adopted after the Great Recession, Rogoff (2017) studied the effects of low interest rates and Tercero-Lucas analysed the effects of unconventional policies on the profitability of commercial banks in Spain. The literature on centralised virtual currencies is also extensive (Barrdear and Kumhof 2016; Griffoli et al. 2018). Authors have analysed the effects of the implementation of CBDCs in several articles (Náñez Alonso et al. 2020a, 2020b, 2021b). In 2017 the Venezuelan government announced the creation of Petro, a state-owned cryptocurrency backed by oil reserves. The aim was to avoid international sanctions (Chohan 2018), but it has not been successful due to continuous technical changes and distrust of the government. The Sand Dollar, a virtual currency of the Bahamian central bank, has been available since October 2020, but many countries are studying it and others are at a very advanced stage for its launch. In Europe, Sweden is in the pilot phase and the ECB itself is analysing the creation of a digital Euro (Mayer 2019; ECB 2020). Although these projects predate the COVID-19 pandemic, they have been accelerated by the new scenario. In fact, the PBOC conducted a digital Yuan trial in March, at the height of the pandemic, in several cities across the country (Kim 2020). Although CBDCs may have certain advantages (security, speed, efficiency, etc.), there are some risks (ECB 2020). Centralised virtual currencies would remove with the privacy of transactions ensured by cash and can aggravate the problems of traditional banking (Náñez Alonso 2019; Náñez Alonso et al. 2020a). Economic agents can easily transfer their deposits from commercial 
banks to the central bank in the event of any doubt about the solvency of the institution, causing a banking panic. The sector is also trying to adapt to an environment characterised by the digitalisation of financial services and a fall in the traditional financial margin due to negative interest rates. For this reason, bank mergers are likely to take place in the coming years (Tercero-Lucas 2021).

The literature on central banks' response to the COVID-19 pandemic is smaller because of the short time that has elapsed since it started and because we are still immersed in the health crisis. Nevertheless, some studies can be noted (Xing 2020; Lepetit and FuentesAlbero 2020; Lacalle 2020; Ojo D Delaney 2020; Hetzel 2020). Xing (2020) focused on the BOJ's application of Modern Monetary Theory in the context of the pandemic. The second study shows the limited power of central banks in this type of crisis and (Lacalle 2020), in a similar vein, concludes that expansionary monetary policies are not working as expected. Ojo D Delaney (2020) analysed the economic and monetary policy during the pandemic in the UK and Hetzel (2020) studied the Fed's monetary policy during the health crisis. The main contribution of this article is to analyse the long-term effects of monetary policy by comparing the latest economic crises and making predictions that, as far as inflation is concerned, are coming true (the calculations were made in mid-2021 and in November 2021 the US CPI was above $6 \%$, the highest rate for several decades, while in the Eurozone it was above $5 \%$ ).

\section{Materials and Methods}

The research is based on the following assumption:

Hypothesis 1 (H1). Monetary expansion generates distortionary effects in the long run. Although monetary stimuli have not had an impact on the CPI, they are financing excessive public debt and causing unsustainable growth in financial markets.

In our study, in order to show the existing correlations between the variables, we proceeded to apply a bi-variate correlation analysis using IBM's SPSS Statistics program, and on the other hand, for the predictions and confidence of the model we used Tableau Desktop Professional Edition.

First, we applied the linear correlation coefficient. The purpose of this coefficient is to determine the degree of intensity that exists between two data or variables. Therefore, the linear correlation coefficient is used to check when the relationship between two variables is linear and is called the Pearson's correlation coefficient and is part of a statistic whose objective is to check the intensity that exists between the two variables that it aims to define (Sampieri 2018).

For the predictions and confidence of the model data, the Tableau Desktop Professional Edition programme was used, which in turn was used to generate the graphs. The model used in this case, is multiplicative (the component is present and multiplied by the other components to create the overall forecast value) (Granger and Newbold 2014; Chevallier et al. 2019). The multiplicative model assumes that as the data increase so does the seasonal pattern. In this model, the trend and seasonal components are multiplied and then added to the error component. In our study we chose the multiplicative model since the magnitude of the seasonal pattern in the data depends on the magnitude of the data.

For the quality metrics root mean square error (RMSE) was used (Nosratabadi et al. 2020) which is determined by Equation (1):

$$
\sqrt{\left(\frac{1}{n}\right)} \sum \mathrm{e}(t)^{2}
$$

This RMSE allowed us to quantify how different our set of values is. The smaller an RMSE value is, the closer the predicted values are to the observed values. 
We also took into account the mean absolute error (MAE) in our study (Nosratabadi et al. 2020) (Chen et al. 2021). The mean absolute error serves to quantify the accuracy of a prediction technique by comparing predicted versus observed values. It is given in Equation (2):

$$
\frac{1}{n} \sum \mathrm{e}(t)
$$

The mean absolute scaled error (MASE), measures the magnitude of the error compared with the magnitude of the error of a naive short-term forecast as a ratio (Franses 2016) and is determined by Equation (3):

$$
\frac{1 / n}{1 /(n-1)} * \frac{\sum \mathrm{e}(t)}{\Sigma[Y(t)-Y(t-1)]}
$$

Mean absolute percentage error (MAPE) measures the magnitude of the error compared with the magnitude of your data, as a percentage. The errors are the differences between the response values, estimated by the model, and the actual response values for each explanatory value in your data (Granger and Newbold 2014; Franses 2016; Chevallier et al. 2019) and are captured in Equation (4):

$$
100 \frac{1}{n} \Sigma \frac{\mathrm{e}(t)}{A(t)}
$$

The advantage of the MASE metric over the more common MAPE metric is that MASE is defined for the time series containing zero, whereas MAPE is not. In addition, MASE evaluates errors equally, while MAPE evaluates positive and extreme errors more severely.

Finally, the Akaike Information Criterion (AIC) was also used as a measure of model quality. It is a measure of model quality, which penalises complex models to prevent overfitting. In this definition, $\mathrm{k}$ is the number of estimated parameters, including initial states, and SSE is the sum of squared errors (Lopez and Weber 2017; Liu et al. 2019). It is defined by Equation (5):

$$
n * \log (S S E / n)+2 *(k+1)
$$

\section{Results}

Table 1 shows the descriptive statistics of the study carried out, followed by Table 2, which shows the bi-variate correlations between the variables studied.

As can be seen in Table 2, the results of the correlations are shown. A perfect positive correlation exists when the result is equal to 1 , if it is between 0.9 and 0.99 it is a very high positive correlation and if it is between 0.7 and 0.89 it is a high positive correlation (Keller 2014; Suárez and Orlando 2011, 2018). Firstly, the correlation between M2 (Japan) and M3 (Eurozone and USA) with debt to GDP is observed. In the Eurozone, M3 and Debt to GDP are positively correlated (0.691), so that as M3 increases, debt increases. This is also the case in Japan and the USA where the growth of M2 and M3, respectively, also generate a growth of debt over GDP (0.345 and 0.915 , respectively).

Second, we observed the correlation between M2 (Japan) and M3 (Eurozone and USA) with CPI. In both the Eurozone and Japan we found a negative correlation $(-0271$ and -0.420 , respectively). This means that M2 and M3 growth is not generating inflation. In the case of the USA the correlation is positive (0.314) but weak.

Thirdly, we observed the correlation between M2 (Japan) and M3 (Eurozone and USA) with the rate of change in GDP. In all three cases (Eurozone, USA and Japan) the correlation is negative $(-0.751,-0754$ and -0.840 , respectively). This means that M2 and M3 growth is not leading to GDP growth, as both variables vary in different directions. 
Table 1. Descriptive statistics.

\begin{tabular}{|c|c|c|c|c|c|c|c|c|c|}
\hline & \multirow{2}{*}{$\begin{array}{c}\mathrm{N} \\
\text { Statistician }\end{array}$} & \multirow{2}{*}{$\begin{array}{c}\text { Minimum } \\
\text { Statistician }\end{array}$} & \multirow{2}{*}{$\begin{array}{c}\text { Maximum } \\
\text { Statistician }\end{array}$} & \multirow{2}{*}{$\begin{array}{c}\text { Average } \\
\text { Statistician }\end{array}$} & \multirow{2}{*}{$\begin{array}{c}\text { Deviation } \\
\text { Statistician }\end{array}$} & \multicolumn{2}{|c|}{ Asymmetry } & \multicolumn{2}{|c|}{ Kurtosis } \\
\hline & & & & & & Statistician & Dev. Error & Statistician & Dev. Error \\
\hline Time & 19 & 01-FEB-12 & 01-FEB-21 & 28-SEP-16 & $\begin{array}{c}1029 \\
13: 09: 42,187\end{array}$ & -0.020 & 0.524 & -1.188 & 1.014 \\
\hline M3 Eurozone (\%) & 19 & $1.00 \%$ & $12.30 \%$ & $4.7421 \%$ & $2.66215 \%$ & 1.712 & 0.524 & 3.684 & 1.014 \\
\hline $\begin{array}{c}\text { M3 Fed USD (billion } \\
\text { USD) }\end{array}$ & 18 & 97731 & 19188 & 13014 & 2296 & 0.994 & 0.536 & 1.668 & 1.038 \\
\hline M2 Japan & 19 & 0.021 & 0.094 & 0.03895 & 0.020024 & 2.231 & 0.524 & 4.546 & 1.014 \\
\hline Public Debt/GDP US & 12 & 1.0332 & 1.0868 & 1.058450 & 0.0171112 & 0.519 & 0.637 & -0.678 & 1.232 \\
\hline $\begin{array}{c}\text { Public Debt/GDP } \\
\text { Japan }\end{array}$ & 8 & 2.2868 & 2.3657 & 2.340050 & 0.0294747 & -0.910 & 0.752 & -0.388 & 1.481 \\
\hline $\begin{array}{l}\text { Public Debt/GDP } \\
\text { Eurozone }\end{array}$ & 9 & 0.7930 & 0.9730 & 0.850556 & 0.0525383 & 1.690 & 0.717 & 3.915 & 1.400 \\
\hline CPI Eurozone (\%) & 19 & $-0.60 \%$ & $2.70 \%$ & $1.0632 \%$ & $0.87000 \%$ & -0.114 & 0.524 & -0.435 & 1.014 \\
\hline CPI US (\%) & 19 & $-0.70 \%$ & $0.40 \%$ & $0.0474 \%$ & $0.26113 \%$ & -1.379 & 0.524 & 2.459 & 1.014 \\
\hline CPI Japan (\%) & 19 & $-1.20 \%$ & $2.40 \%$ & $0.5421 \%$ & $0.96108 \%$ & 0.178 & 0.524 & -0.114 & 1.014 \\
\hline M.C Dow Jones & 19 & 181,327 & $3,152,275$ & $1,787,339.26$ & $894,812.076$ & -0.448 & 0.524 & -0.316 & 1.014 \\
\hline M. C Nikkei 225 & 19 & 9723.24 & $28,966.01$ & $18,936.6037$ & 5156.12085 & -0.036 & 0.524 & -0.046 & 1.014 \\
\hline M. C Eurostoxx 50 & 19 & 2523.69 & 3800.00 & 3227.8389 & 377.86144 & -0.340 & 0.524 & -0.592 & 1.014 \\
\hline $\begin{array}{c}\text { Annual GDP } \\
\text { Variation Rate US }\end{array}$ & 9 & $-3.50 \%$ & $3.10 \%$ & $1.7000 \%$ & $2.00624 \%$ & -2.681 & 0.717 & 7.639 & 1.400 \\
\hline $\begin{array}{c}\text { Annual GDP } \\
\text { Variation Rate Japan } \\
\text { Annual GDP }\end{array}$ & 9 & $-4.80 \%$ & $2.20 \%$ & $0.3889 \%$ & $2.04539 \%$ & -2.449 & 0.717 & 6.743 & 1.400 \\
\hline $\begin{array}{c}\text { Variation Rate } \\
\text { Eurozone }\end{array}$ & 9 & -0.06600 & 0.02600 & 0.0036667 & 0.02847806 & -2.198 & 0.717 & 5.216 & 1.400 \\
\hline
\end{tabular}

Source: own elaboration using SPSS 27 and data extracted from the International Monetary Fund, ECB, Fed, and $\mathrm{BOJ}$.

Table 2. Statistical correlation between M2-M3 and public debt, CPI, GDP growth rate and stock market indices.

\begin{tabular}{|c|c|c|c|c|c|c|c|}
\hline \multicolumn{8}{|c|}{ Correlation M2-M3 with Public Debt } \\
\hline Correl. Pearson & $\begin{array}{c}\text { Public } \\
\text { Debt/GDP US }\end{array}$ & $\begin{array}{c}\text { Public } \\
\text { Debt/GDP } \\
\text { Eurozone }\end{array}$ & $\begin{array}{c}\text { Public } \\
\text { Debt/GDP } \\
\text { Japan }\end{array}$ & Rho Spearman & $\begin{array}{c}\text { Public } \\
\text { Debt/GDP US }\end{array}$ & $\begin{array}{c}\text { Public } \\
\text { Debt/GDP } \\
\text { Eurozone }\end{array}$ & $\begin{array}{c}\text { Public } \\
\text { Debt/GDP } \\
\text { Japan }\end{array}$ \\
\hline M3 Eurozone & & 0.691 & & M3 Eurozone & & -0.100 & \\
\hline M3 Fed USD & 0.915 & & & M3 Fed USD & 0.887 & & \\
\hline M2 Japan & & & 0.345 & M2 Japan & & & 0.211 \\
\hline \multicolumn{8}{|c|}{ Correlation M2-M3 with CPI } \\
\hline Correl. Pearson & CPI US & CPI Eurozone & CPI Japan & Rho Spearman & CPI US & $\begin{array}{c}\text { CPI } \\
\text { Eurozone }\end{array}$ & CPI Japan \\
\hline M3 Eurozone & & -0.271 & & M3 Eurozone & & -0.219 & \\
\hline M3 Fed USD & 0.314 & & & M3 Fed USD & 0.358 & & \\
\hline M2 Japan & & & -0.42 & M2 Japan & & & 0.101 \\
\hline \multicolumn{8}{|c|}{ Correlation M2-M3 with Variation Rate GDP } \\
\hline Correl. Pearson & V. R GDP US & $\begin{array}{l}\text { V.R GDP } \\
\text { Eurozone }\end{array}$ & V.R GDPJapan & Rho Spearman & V. R GDP US & $\begin{array}{l}\text { V.R GDP } \\
\text { Eurozone }\end{array}$ & V.R GDP Japan \\
\hline M3 Eurozone & & -0.675 & & M3 Eurozone & & 0.021 & \\
\hline M3 Fed USD & -0.754 & & & M3 Fed USD & -0.176 & & \\
\hline M2 Japan & & & -0.84 & M2 Japan & & & 0 \\
\hline \multicolumn{8}{|c|}{ Correlation M2-M3 with Selected Stock Index } \\
\hline Correl. Pearson & Dow Jones & Nikkei 225 & Eurostoxx50 & Rho Spearman & Dow Jones & Nikkei 225 & Eurostoxx50 \\
\hline M3 Eurozone & & & 0.486 & M3 Eurozone & & & 0.652 \\
\hline M3 Fed USD & 0.552 & & & M3 Fed USD & 0.688 & & \\
\hline M2 Japan & & 0.622 & & M2 Japan & & 0.28 & \\
\hline
\end{tabular}

Source: own elaboration using SPSS 27 and data extracted from the International Monetary Fund, ECB, Fed, and $\mathrm{BOJ}$.

Fourth and finally, the correlation between M2 (Japan) and M3 (Eurozone and USA) with the selected stock market indices is observed. Both the Eurozone and Japan show a positive correlation ( 0.680 and 0.622 , respectively). In the case of $\mathrm{M} 3$ and the capitalisation of the Dow Jones, a positive correlation is also observed (0.552). 
This means that both variables vary in the same direction and that therefore a growth of M2 and M3 leads to a growth of the stock market index.

Analysing the evolution of Fed assets (Table 3) we observe a strong positive correlation (0.799) with public debt over GDP and also a positive, but somewhat weaker correlation with CPI (0.31) indicating that both variables are moving in the same direction. The more assets issued by the Fed, the more government debt, but this is not translating into higher inflation so far.

Table 3. Correlation of balance sheet expansion with public debt and CPI.

\begin{tabular}{ccccc}
\hline Correl. Pearson & $\begin{array}{c}\text { Public } \\
\text { Debt/GDP US }\end{array}$ & $\begin{array}{c}\text { Public } \\
\text { Debt/GDP } \\
\text { Eurozone }\end{array}$ & CPI Eurozone & CPI US \\
\hline Fed Assets & 0.799 & & 0.453 & 0.31 \\
\hline ECB Assets & & -0.948 & CPI US \\
Rho Spearman & Public & $\begin{array}{c}\text { Public } \\
\text { Debt/GDP } \\
\text { Eurozone }\end{array}$ & CPI Eurozone & -0.06 \\
\hline Fed Assets & 0.337 & & 0.595 & \\
\hline ECB Assets & & -0.970 & & \\
\hline
\end{tabular}

Source: own elaboration using SPSS 27 and data extracted from the International Monetary Fund, ECB, Fed and BOJ.

As for the ECB's balance sheet, Table 3 shows an inverse correlation as ECB assets and Eurozone public debt vary in different directions $(-0.948)$ while, with the CPI, ECB assets have a positive correlation, albeit weak (0.453) so that, as in the US with the Fed, the expansion of the balance sheet has not yet reached the economy via inflation.

At this point, the results of our predictions are analysed to see whether monetary expansion generates distortionary effects in the long run. Although monetary stimulus has not had an impact on the CPI (as we saw in the correlation analysis), it is financing excessive government borrowing and causing unsustainable growth in financial markets. Table 4 shows the model and the metrics that are described in the methodology section.

Figure 1 shows the relationship between M2 and M3 with public debt over GDP. In the case of the USA, M3 will grow and public doubt about GDP will also grow; in the Eurozone there will be an increase in M3 but public debt as a percentage of GDP will fall slightly; while in Japan there will be a slight fall in M2 and doubt about GDP will continue to grow. Figure 2 shows the relationship between M2-M3 and the evolution of the CPI. In the case of both the Euro-zone and the US, M3 is expected to grow, which will bring with it an increase in CPI, while in Japan, despite a slight fall in M2, CPI will grow somewhat. Therefore, we see that one of our hypotheses is fulfilled and that eventually the money supply will start to cause inflation in the economy. 
Table 4. Model and quality metrics.

\begin{tabular}{|c|c|c|c|c|c|c|c|}
\hline \multicolumn{8}{|c|}{ Sum of Public Debt/GDP Eurozone } \\
\hline \multicolumn{3}{|c|}{ Model } & \multicolumn{5}{|c|}{ Quality Metrics } \\
\hline Level & Trend & Season & RMSE & MAE & MASE & MAPE & AIC \\
\hline Additive & None & None & 0.360 & 0.293 & 1.23 & $19.2 \%$ & -4 \\
\hline \multicolumn{8}{|c|}{ Sum of Public Debt/GDP US } \\
\hline \multicolumn{3}{|c|}{ Model } & \multicolumn{5}{|c|}{ Quality Metrics } \\
\hline Level & Trend & Season & RMSE & MAE & MASE & MAPE & AIC \\
\hline Additive & None & Additive & 0.36 & 0.293 & 1.23 & $19.20 \%$ & -4 \\
\hline \multicolumn{8}{|c|}{ Sum of Public Debt/GDP Japan } \\
\hline \multicolumn{3}{|c|}{ Model } & \multicolumn{5}{|c|}{ Quality Metrics } \\
\hline Level & Trend & Season & RMSE & MAE & MASE & MAPE & AIC \\
\hline Additive & None & None & 0.903 & 0.367 & 0.45 & $8.30 \%$ & 5 \\
\hline \multicolumn{8}{|c|}{ Sum of M2 Japan } \\
\hline \multicolumn{3}{|c|}{ Model } & \multicolumn{5}{|c|}{ Quality Metrics } \\
\hline Level & Trend & Season & RMSE & MAE & MASE & MAPE & AIC \\
\hline Additive & None & None & 0.02052 & 0.01524 & 0.8 & $19.50 \%$ & -72 \\
\hline \multicolumn{8}{|c|}{ Sum of M3 Eurozone } \\
\hline \multicolumn{3}{|c|}{ Model } & \multicolumn{5}{|c|}{ Quality Metrics } \\
\hline Level & Trend & Season & RMSE & MAE & MASE & MAPE & AIC \\
\hline Additive & Additive & None & 0.0209 & 0.0149 & 0.66 & $22.00 \%$ & -67 \\
\hline \multicolumn{8}{|c|}{ Sum of M3 Fed USD } \\
\hline \multicolumn{3}{|c|}{ Model } & \multicolumn{5}{|c|}{ Quality Metrics } \\
\hline Level & Trend & Season & RMSE & MAE & MASE & MAPE & AIC \\
\hline Multiplicative & Multiplicative & None & 1.817.147.30 & 289.046 .256 .037 & 0.72 & $5.20 \%$ & 518 \\
\hline \multicolumn{8}{|c|}{ Sum of CPI US } \\
\hline \multicolumn{3}{|c|}{ Model } & \multicolumn{5}{|c|}{ Quality Metrics } \\
\hline Level & Trend & Season & RMSE & MAE & MASE & MAPE & AIC \\
\hline Additive & None & None & 0.00449 & 0.00343 & 0.84 & $72.90 \%$ & -102 \\
\hline \multicolumn{8}{|c|}{ Sum of CP Eurozone } \\
\hline \multicolumn{3}{|c|}{ Model } & \multicolumn{5}{|c|}{ Quality Metrics } \\
\hline Level & Trend & Season & RMSE & MAE & MASE & MAPE & AIC \\
\hline Additive & None & None & 0.01512 & 0.0132 & 1.02 & $113.60 \%$ & -78 \\
\hline \multicolumn{8}{|c|}{ Sum of CPI Japan } \\
\hline & Model & & & & lity Met & & \\
\hline Level & Trend & Season & RMSE & MAE & MASE & MAPE & AIC \\
\hline Additive & None & None & 0.01503 & 0.01319 & 0.97 & $341.20 \%$ & -78 \\
\hline & & & Sum of V. & Eurozone & & & \\
\hline & Model & & & & lity Met & & \\
\hline Level & Trend & Season & RMSE & MAE & MASE & MAPE & AIC \\
\hline Additive & None & None & 0.02691 & 0.01917 & 1.19 & $107.2 \%$ & -59 \\
\hline
\end{tabular}


Table 4. Cont.

Sum of V. R. GDP US

\begin{tabular}{|c|c|c|c|c|c|c|c|}
\hline \multicolumn{3}{|c|}{ Model } & \multicolumn{5}{|c|}{ Quality Metrics } \\
\hline Level & Trend & Season & RMSE & MAE & MASE & MAPE & AIC \\
\hline Additive & None & None & 0.02015 & 0.01016 & 0.75 & $34.80 \%$ & -64 \\
\hline \multicolumn{8}{|c|}{ Sum of V.R. GDP Japan } \\
\hline \multicolumn{3}{|c|}{ Model } & \multicolumn{5}{|c|}{ Quality Metrics } \\
\hline Level & Trend & Season & RMSE & MAE & MASE & MAPE & AIC \\
\hline Additive & None & None & 0.02012 & 0.01206 & 0.78 & $115.40 \%$ & -64 \\
\hline \multicolumn{8}{|c|}{ Sum of M. C Euro Stoxx 50} \\
\hline \multicolumn{3}{|c|}{ Model } & \multicolumn{5}{|c|}{ Quality Metrics } \\
\hline Level & Trend & Season & RMSE & MAE & MASE & MAPE & AIC \\
\hline Additive & None & None & 1.024 & 818 & 0.93 & $15.4 \%$ & 145 \\
\hline \multicolumn{8}{|c|}{ Sum of M. C Dow Jones } \\
\hline \multicolumn{3}{|c|}{ Model } & \multicolumn{5}{|c|}{ Quality Metrics } \\
\hline Level & Trend & Season & RMSE & MAE & MASE & MAPE & AIC \\
\hline Additive & None & None & 10.675 & 9.348 & 1.05 & $28.50 \%$ & 192 \\
\hline \multicolumn{8}{|c|}{ Sum of M. C Nikkei 225} \\
\hline \multicolumn{3}{|c|}{ Model } & \multicolumn{5}{|c|}{ Quality Metrics } \\
\hline Level & Trend & Season & RMSE & MAE & MASE & MAPE & AIC \\
\hline Additive & None & None & 7.855 & 6.754 & 1.14 & $21.10 \%$ & 185 \\
\hline \multicolumn{8}{|c|}{ Sum of ECB Assets } \\
\hline \multicolumn{3}{|c|}{ Model } & \multicolumn{5}{|c|}{ Quality Metrics } \\
\hline Level & Trend & Season & RMSE & MAE & MASE & MAPE & AIC \\
\hline Multiplicative & Multiplicative & None & 553.443 & 472.974 & 1.02 & $18.40 \%$ & 222 \\
\hline \multicolumn{8}{|c|}{ Sum of Fed Assets } \\
\hline \multicolumn{3}{|c|}{ Model } & \multicolumn{5}{|c|}{ Quality Metrics } \\
\hline Level & Trend & Season & RMSE & MAE & MASE & MAPE & AIC \\
\hline Additive & None & None & 1.210 .185 & 796.204 & 1.09 & $16.20 \%$ & 230 \\
\hline
\end{tabular}

Source: prepared by the authors using Tableau Desktop professional edition and data from the International Monetary Fund, ECB, Fed, and BOJ. 


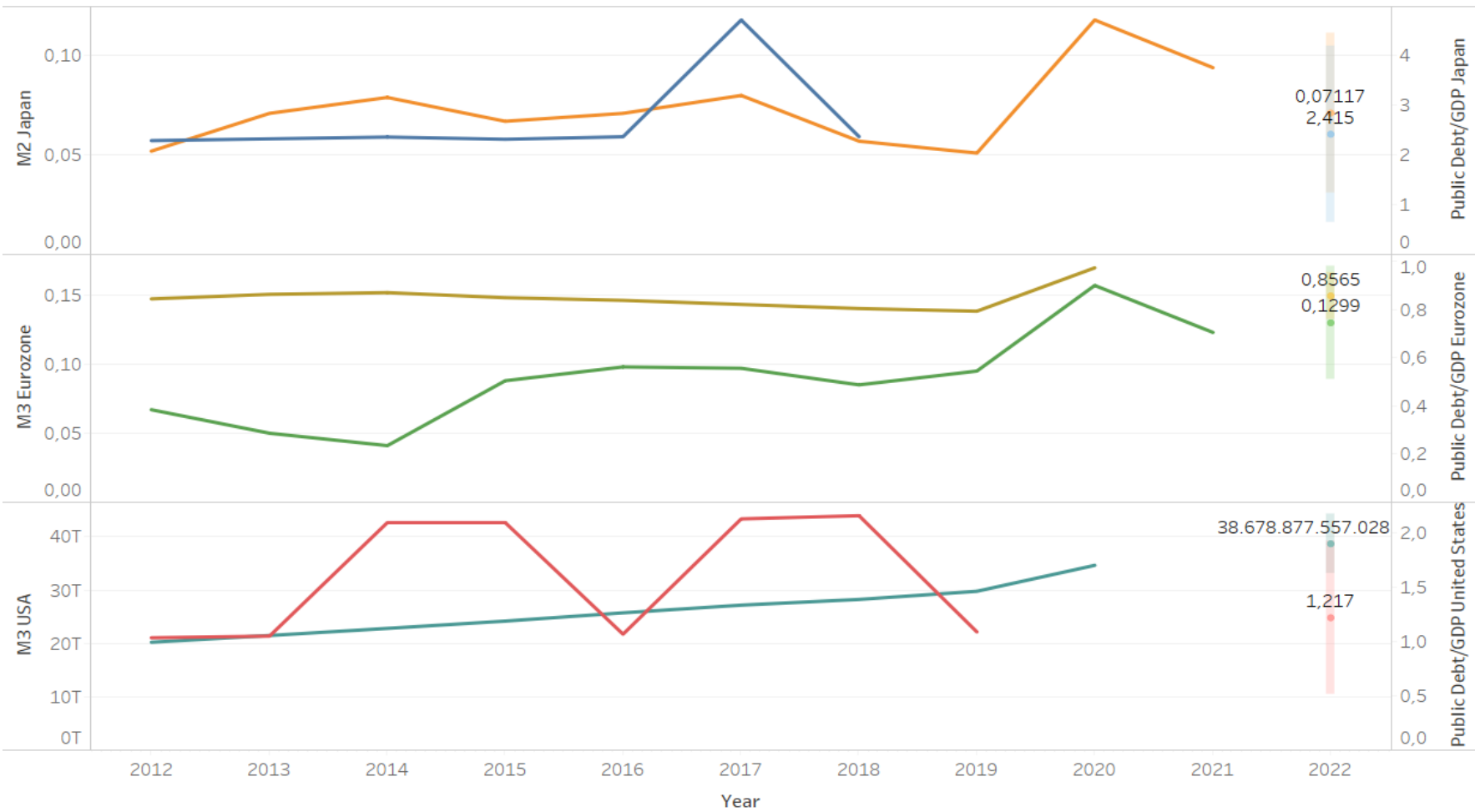

Figure 1. M2-M3 ratio with public debt/GDP prediction. Source: own elaboration via Tableau Desktop professional edition and data from the International Monetary Fund, ECB, Fed, and BOJ.

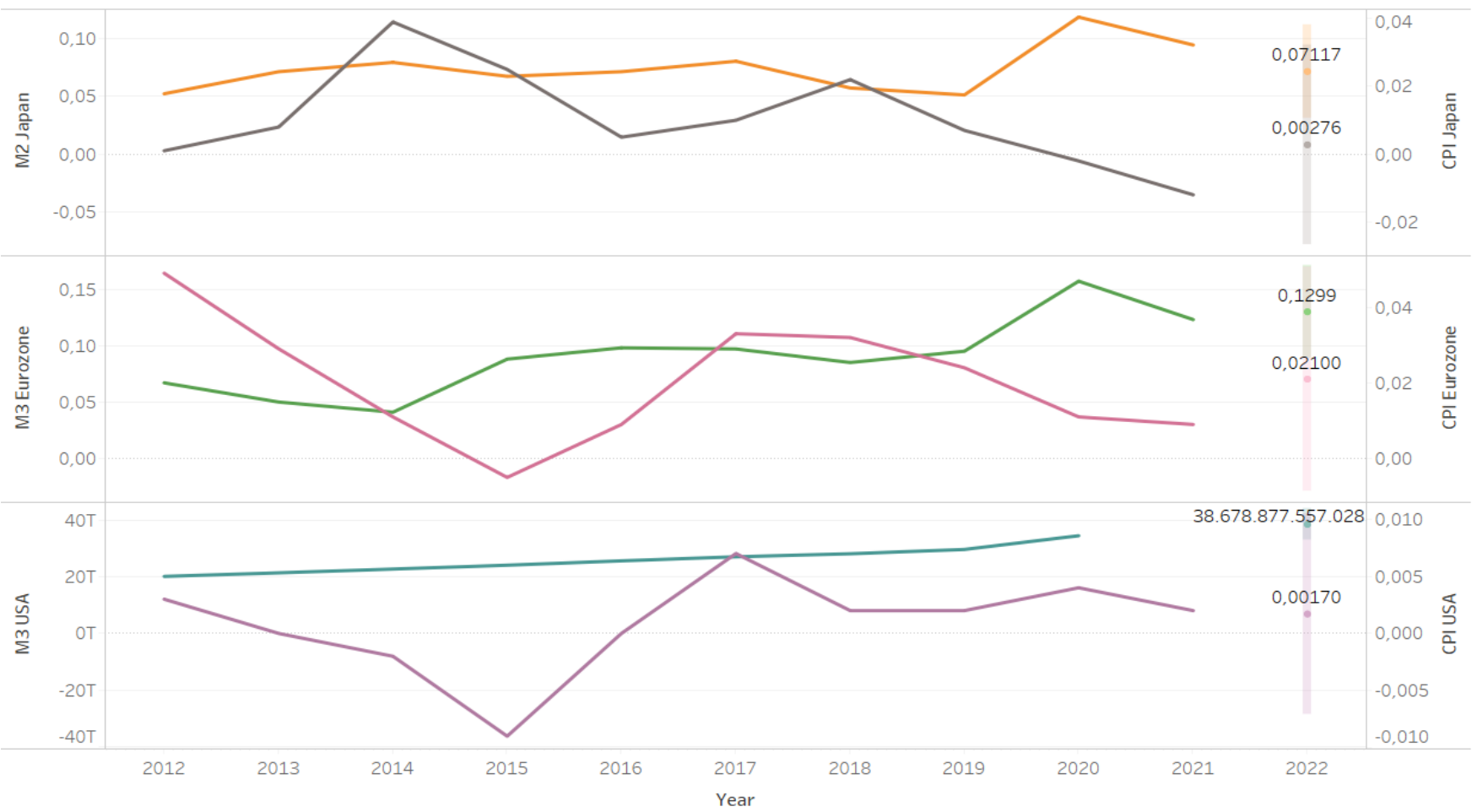

Figure 2. M2-M3 ratio with CPI and prediction. Source: prepared by the authors using Tableau Desktop professional edition and data from the International Monetary Fund, ECB, Fed, and BOJ.

Figure 3 shows the relationship between M2-M3 and the rate of change in GDP. In this case, in both the US and the Eurozone, M3 will grow and this will lead to GDP growth, while in Japan we see a slight decrease in M2 and a slight improvement in GDP. 


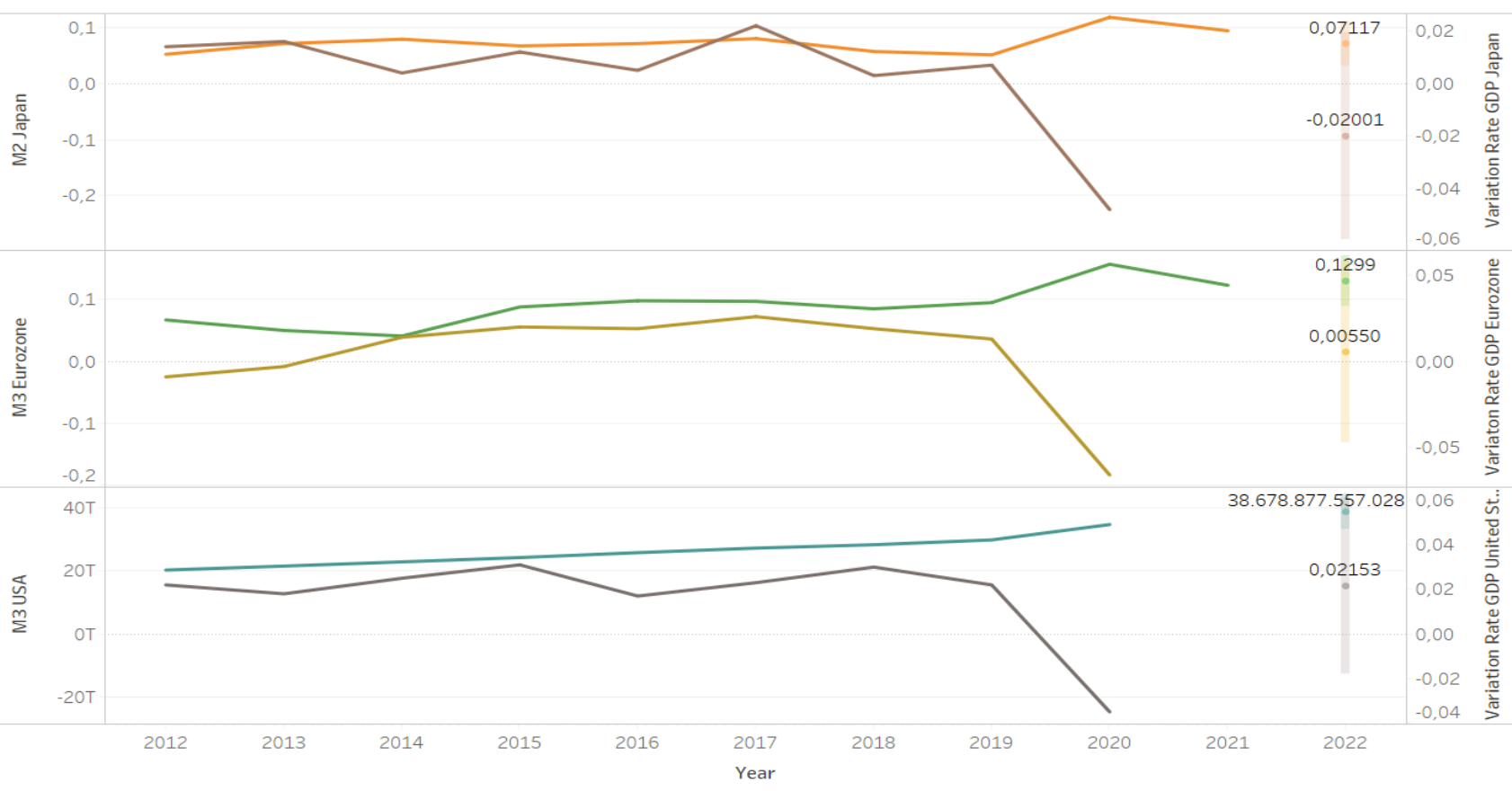

Figure 3. M2-M3 ratio with variation rate/GDP and prediction. Source: own elaboration through Tableau Desktop professional edition and data from International Monetary Fund, ECB, Fed, and BOJ.

Figure 4 shows the relationship between M2-M3 and market capitalisation. In the case of Japan, a slight fall in M2 is expected, and an increase in the market capitalisation of its benchmark index: Nikkei. In the case of the Eurozone and the USA, a growth in M3 is expected, which will bring with it an increase in their benchmark indices: the Eurostoxx50 and the Dow Jones, respectively.

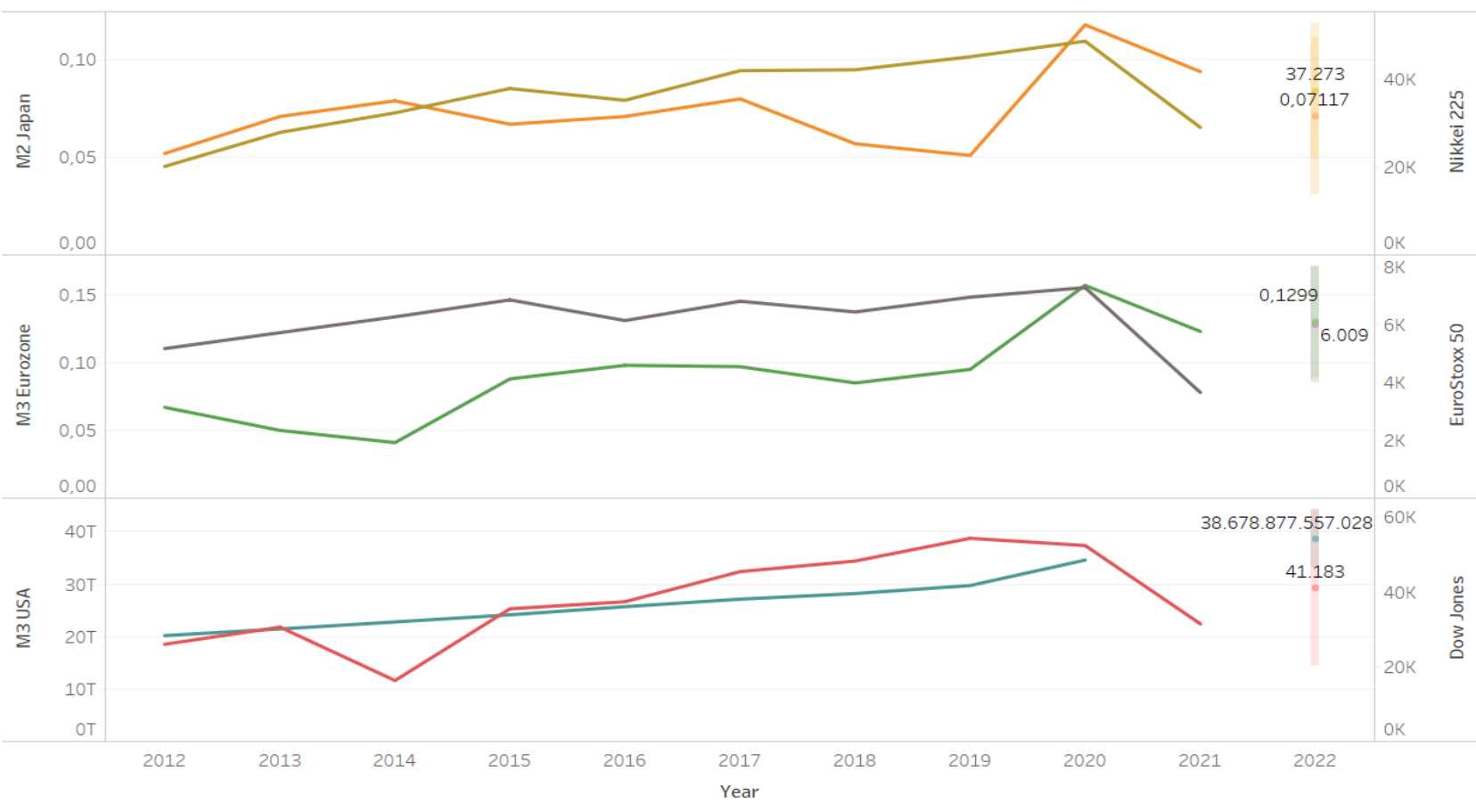

Figure 4. M2-M3 ratio with Market Capitalization and prediction. Source: own elaboration through Tableau Desktop professional edition and data from International Monetary Fund, ECB, Fed, and BOJ. 
Finally, and turning to the expansion of the ECB's and the Fed's balance sheets, the results are shown in Figures 5 and 6.

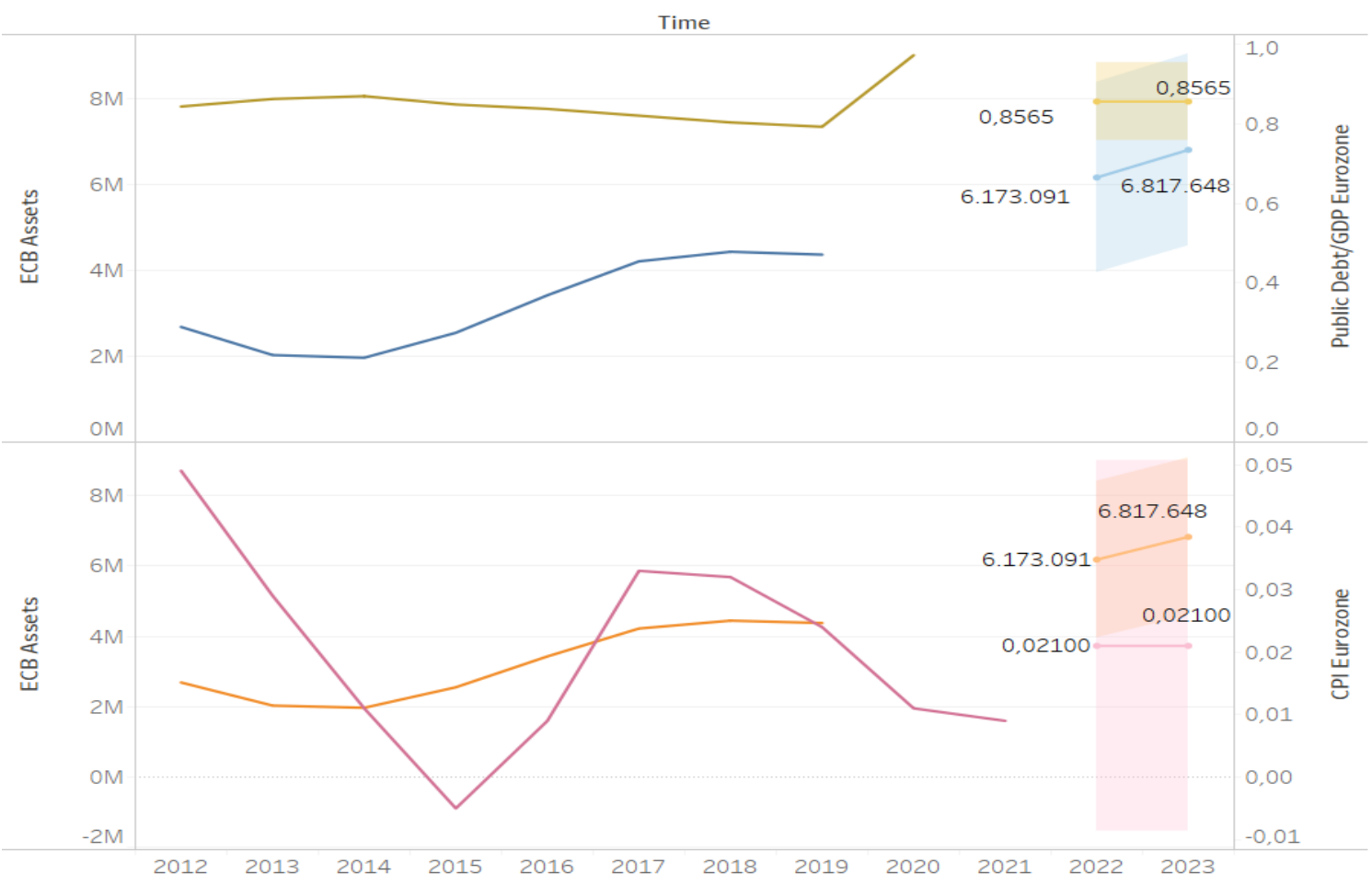

Figure 5. Expansion balance sheet with public debt and CPI (Eurozone). Source: prepared by the authors using Tableau Desktop professional edition and data from the International Monetary Fund, ECB, Fed, and BOJ.

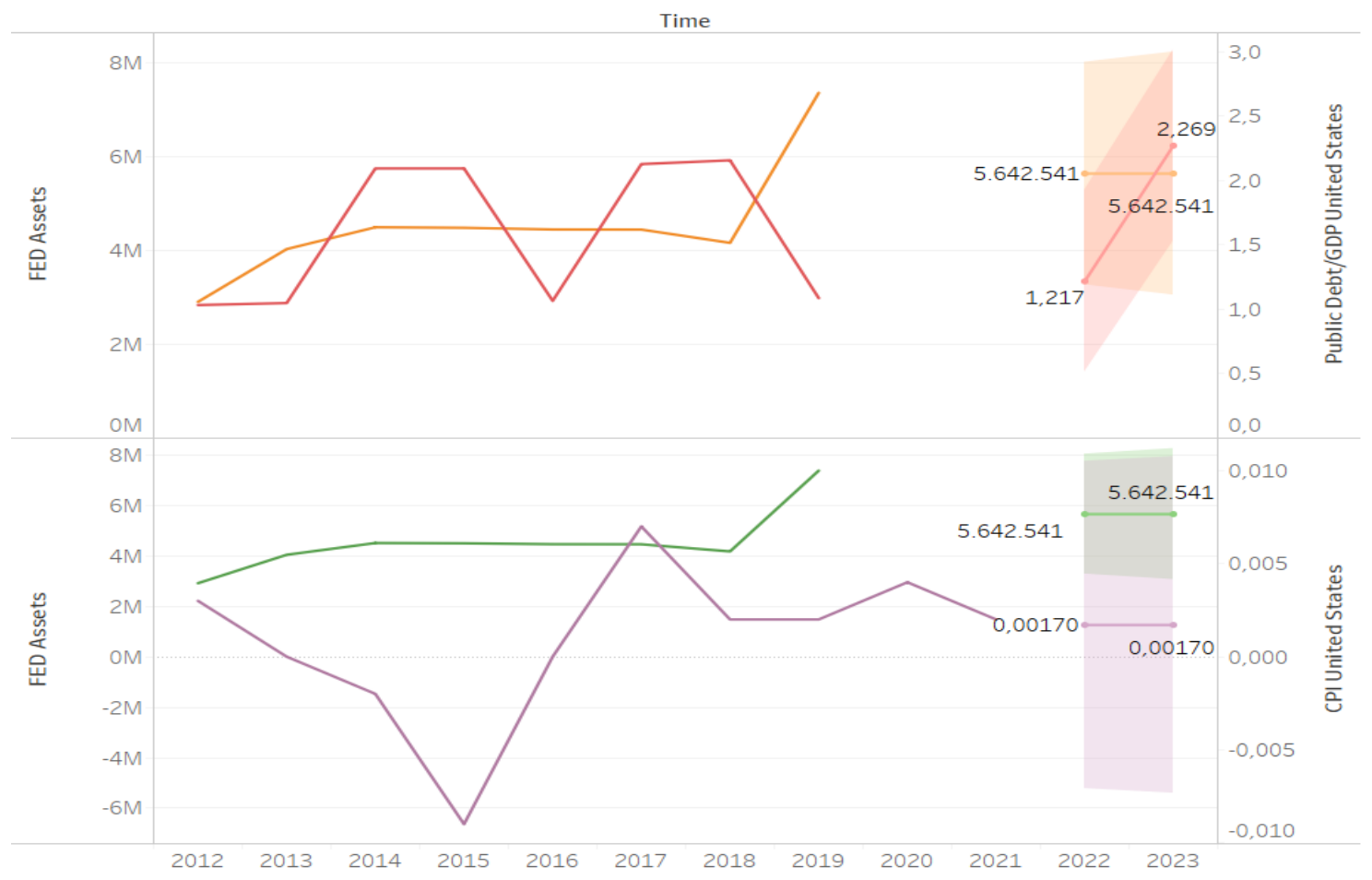

Figure 6. Expansion balance sheet with public debt and CPI (USA). Source: Prepared by the authors using Tableau Desktop professional edition and data from the International Monetary Fund, ECB, Fed, and BOJ. 
In the case of the ECB, assets will continue to grow strongly while debt to GDP in the euro zone will continue to fall and CPI will grow steadily.

In the case of the FED, assets will stop growing; however, the excesses of previous years show in the forecast how the debt to GDP of the USA will continue to grow steadily and a certain stagnation of the CPI.

\section{Discussion}

The method used to relate monetary policy to different variables has been widely used in the economic literature, as shown in the studies by Ortiz Zarco and Perrotini Ortiz Zarco and Perrotini Hernández (2019) in the case of Mexico, Canada, and the United States, and in the specific case of the United States (Gokmenoglu and Hadood 2020). For the case of Colombia, it has been studied by Parra Barrios (2019) and in the case of China, the study by Fidrmuc and Korhonen (2016) stands out. In Europe, we can mention the studies on Portugal by Afonso and Silva (2019), that of Ukraine (Baranovskyi et al. 2019), Croatia (Perović 2015), or the entire Eastern European area (Hegerty 2016) and on the Eurozone itself: (Guerello 2018; Kenourgios et al. 2019). It has also been studied in Malaysia (Hossain 2017). A similar methodology has been employed in the study of other areas of the social sciences (Reier Forradellas et al. 2021).

The predictions that were made are tentative due to the environment of high economic uncertainty in which we find ourselves (Rutter et al. 2020). In many countries, mobility restriction measures remain in place, and depending on when they are lifted and the economic situation, macroeconomic variables can change rapidly. For example, an increase in the velocity of money circulation can rapidly increase the CPI as the increase in money supply can be accompanied by an increase in consumption after several months of subdued demand. The fact that the Fed, for example, raises interest rates at a given moment also influences the ECB's monetary policy. In other words, there are many factors that the study cannot take into account.

There are different studies that try to predict the consequences of central banks' monetary policy. Ahmed (2019) showed that there is a long-run equilibrium between the monetary base and government bonds and makes different estimates. Parella (2018) showed the negative consequences of expansionary policies after the Great Recession. The study shows that monetary expansion has not generated economic growth and has been channelled into public debt and financial markets. Cai (2019), in turn, showed the causal relationship between monetary expansion and resource misallocation in China. The study by Alonso-Rivera (2019) shows a similar result to this article. It shows that increasing the money supply and lowering interest rates generate inefficiencies in financial markets through the creation of asset bubbles.

\section{Conclusions}

Central banks reacted to recent economic crises with monetary stimulus policies based on maintaining low interest rates and purchasing a large share of the public debt issued by governments to meet public spending. While these policies can temporarily stabilise the situation, they can also generate distortions if perpetuated indefinitely. Monetary expansion is starting to have an impact on the CPI. There is a risk of public debt overhang, massive investment errors and a spike in inflation in the coming years. Central banks are faced with a dilemma: although they must raise interest rates or withdraw stimulus (tapering), as the Fed recently announced, to curb inflation this would be a major financial problem for most governments, which are heavily indebted.

In the midst of these crises, there have been major changes in the monetary system with the emergence of private cryptocurrencies, new electronic means of payment and the emergence of centralised virtual currencies issued by central banks. The analysis of the effects of these currencies on monetary policy and, in particular, on commercial banks is an open topic for future research, as most countries are currently studying it. The study we presented has some limitations: the prediction made may be altered in a context of great 
uncertainty such as the one we are currently experiencing. The pandemic has not subsided and the vaccination process has not been completed in many countries. Moreover, it is very likely that in the coming months and years there will be many changes in economic policy in most countries.

Author Contributions: Data curation, M.Á.E.F. and S.L.N.A.; Formal analysis, M.Á.E.F.; Investigation, M.Á.E.F. and R.R.F.; Methodology, S.L.N.A.; Resources, J.J.-V.; Supervision, R.R.F. and J.J.-V.; Writing—original draft, M.Á.E.F.; Writing—review \& editing, S.L.N.A. All authors have read and agreed to the published version of the manuscript.

Funding: This research received no external funding.

Informed Consent Statement: Informed consent was obtained from all subjects involved in the study.

Conflicts of Interest: The authors declare no conflict of interest.

\section{References}

Afonso, Antonio, and Jorge Silva. 2019. Efectos de la política monetaria de la zona del euro en los sectores institucionales: El caso de Portugal. Cuadernos De Economía 42: 120. [CrossRef]

Ahmed, Haydory Akbar. 2019. Monetary base and federal government debt in the long-run: A non-linear analysis. Bulletin of Economic Research 72: 167-84. [CrossRef]

Alonso Neira, Miguel Ángel, Philipp Bagus, and Juan Ramón Rallo Julián. 2010. La crisis subprime a la luz de la teoría austríaca del ciclo económico: Expansión crediticia, decision errors and moral hazard. Revista de Economía Mundial 28: 145-74.

Alonso-Rivera, Angélica. 2019. Impact of monetary policy on financial markets efficiency under speculative bubbles: A non-normal and non-linear entropy-based approach. Análisis Económico 34: 157-78. [CrossRef]

Ammous, Saifedean. 2018. The Bitcoin Standard: The Decentralized Alternative to Central Banking. Hoboken: John Wiley \& Sons.

Bagus, Philipp, and David Howden. 2009. The federal reserve and eurosystem's balance sheet policies during the subprime crisis: A comparative analysis. Romanian Economic and Business Review 3: 165-85.

Bagus, Philipp, and David Howden. 2015. Central bank insolvency: Causes, effects, and remedies. Journal of Social, Political and Economics Studies 39: 3-23.

Bagus, Philipp, and Markus Schiml. 2010. A cardiograph of the dollar's quality: Qualitative easing and the federal reserve balance sheet during the subprime crisis. Prague Economic Papers 19: 195-217. [CrossRef]

Baranovskyi, O. I., M. O. Kuzheliev, D. M. Zherlitsyn, O. S. Sokyrko, and A. V. Nechyporenko. 2019. Econometric models of monetary policy effectiveness in Ukraine. Financial and Credit Activity: Problems of Theory and Practice 3: 226-35. [CrossRef]

Barrdear, John, and Michael Kumhof. 2016. The Macroeconomics of Central Bank Issued Digital Currencies. SSRN Electronic Journal, 104148 , in press. [CrossRef]

Cachanosky, Nicolás. 2019. Does Bitcoin Have the Right Monetary Rule? SSRN Electronic Journal. [CrossRef]

Cai, Yue. 2019. Expansionary monetary policy and credit misallocation: Evidence from China. SSRN Electronic Journal. [CrossRef]

Chen, Wei, Huilin Xu, Lifen Jia, and Ying Gao. 2021. Machine learning model for Bitcoin exchange rate prediction using economic and technology determinants. International Journal of Forecasting 37: 28-43. [CrossRef]

Chevallier, Julien, Stéphane Goutte, David Guerreiro, Sophie Saglio, and Bilel Sanhaji, eds. 2019. Financial Mathematics, Volatility and Covariance Modelling: Volume 2. Milton Park: Routledge.

Chohan, Usman. 2018. Cryptocurrencies as asset-backed instruments: The venezuelan petro. SSRN Electronic Journal. [CrossRef]

De Soto, Jesús Huerta. 2012. Money, Bank Credit, and Economic Cycles. Auburn: Ludwig von Mises Institute.

ECB (European Central Bank). 2020. Report on a Digital Euro. Frankfurt: European Central Bank.

Echarte Fernández, Miguel Ángel, Sergio Luis Náñez Alonso, Javier Jorge-Vázquez, and Ricardo Francisco Reier Forradellas. 2021. Central banks' monetary policy in the face of the COVID-19 economic crisis: Monetary stimulus and the emergence of CBDCs. Sustainability 13: 4242. [CrossRef]

Espinosa, Victor, Miguel Ángel. Alonso Neira, and Jesús Huerta de Soto. 2021. Principles of sustainable economic growth and development: A call to action in a post-COVID-19 world. Sustainability 13: 13126. [CrossRef]

Fabris, Nikola. 2019. Cashless Society-The Future of Money or a Utopia? Journal of Central Banking Theory and Practice 8: 53-66. [CrossRef]

Fidrmuc, Jarko, and Iikka Korhonen. 2016. Meta-Analysis of Chinese Business Cycle Correlation. Pacific Economic Review 23: 385-410. [CrossRef]

Franses, Philip Hans. 2016. A note on the Mean Absolute Scaled Error. International Journal of Forecasting 32: 20-22. [CrossRef]

Fukuda, Shin-Ichi. 2018. Impacts of Japan's negative interest rate policy on Asian financial markets. Pacific Economic Review 23: 67-79. [CrossRef]

Gokmenoglu, Korhan, and Abobaker Al Al Hadood. 2020. Impact of US unconventional monetary policy on dynamic stock-bond correlations: Portfolio rebalancing and signalling channel effects. Finance Research Letters 33: 101185. [CrossRef] 
Granger, Clive, and Paul Newbold. 2014. Forecasting Economic Time Series. Cambridge: Academic Press.

Griffoli, Tommaso Mancini, Maria Soledad Martinez Peria, Itai Agur, Anil Ari, John Kiff, Adina Popescu, and Celine Rochon. 2018. Casting Light on Central Bank Digital Currencies. Washington, DC: International Monetary Fund.

Guerello, Chiara. 2018. Conventional and unconventional monetary policy vs. households income distribution: An empirical analysis for the Euro Area. Journal of International Money and Finance 85: 187-214. [CrossRef]

Guerini, Mattia, Francesco Lamperti, and Andrea Mazzocchetti. 2018. Unconventional Monetary Policy: Between the Past and Future of Monetary Economics. SSRN Electronic Journal 15: 122-31. [CrossRef]

Hegerty, Scott. 2016. Inflation volatility, monetary policy, and exchange-rate regimes in central and eastern europe: Evidence from parametric and nonparametric analyses. Eastern European Economics 55: 70-90. [CrossRef]

Hetzel, R. L. 2020. COVID-19 and the fed's monetary policy. SSRN Electronic Journal. [CrossRef]

Hossain, Akhand Akhtar. 2017. Monetary policy for maintaining low, stable inflation in Malaysia. The Journal of Developing Areas 51: 381-404. [CrossRef]

Ito, Takatoshi, Kazumasa Iwata, Colin McKenzie, and Shujiro Urata. 2018. Did abenomics succeed?: Editors' overview. Asian Economic Policy Review 13: 1-22. [CrossRef]

Kaczmarek, Jaroslaw, Alonso Sergio Luis Náñez, Sokołowski Andrzej, Fijorek Kamil, and Denkowska Sabina. 2021. Financial threat profiles of industrial enterprises in Poland. Oeconomia Copernicana 12: 463-98. [CrossRef]

Kawai, Masahiro, and Peter Morgan. 2013. Banking crises and "Japanization": Origins and implications. SSRN Electronic Journal. [CrossRef]

Keller, Gerald. 2014. Statistics for Management and Economics. Boston: Cengage Learning.

Kenourgios, Dimitris, Emmanouela Drakonaki, and Dimitrios Dimitriou. 2019. ECB's unconventional monetary policy and crossfinancial-market correlation dynamics. The North American Journal of Economics and Finance 50: 101045. [CrossRef]

Kim, Gi. 2020. Why is China going to issue CBDC (Central Bank Digital Currency)? The Journal of Internet Electronic Commerce Resarch 20: 161-77. [CrossRef]

Lacalle, Daniel. 2020. Monetary and fiscal policies in the COVID-19 crisis. Will they work? Journal of Business Accounting and Finance Perspectives 2: 1. [CrossRef]

Lakdawala, Ali Muhammad. 2016. The War is on "Currency War": Its Impact on Commodities in 2016. SSRN Electronic Journal. [CrossRef]

Lepetit, Antoine, and Cristina Fuentes-Albero. 2020. The limited power of monetary policy in a pandemic. SSRN Electronic Journal. [CrossRef]

Liu, Yongxin, Hok Sum Fok, Robert Tenzer, Qiang Chen, and Xiuwan Chen. 2019. Akaike's bayesian information criterion for the joint inversion of terrestrial water storage using GPS vertical displacements, GRACE and GLDAS in southwest china. Entropy 21: 664. [CrossRef] [PubMed]

Lopez, Luciano, and Sylvain Weber. 2017. Testing for granger causality in panel data. The Stata Journal: Promoting Communications on Statistics and Stata 17: 972-84. [CrossRef]

Mayer, Thomas. 2019. A Digital Euro to Compete With Libra. The Economists' Voice 16. [CrossRef]

Momirovic, Dragan. 2014. Non-standard monetary policy of the ECB: Macroeconomic effects and exit strategy. Bankarstvo 43: 58-85. [CrossRef]

Murota, Ryu-ichiro. 2019. Negative interest rate policy in a permanent liquidity trap. SSRN Electronic Journal. [CrossRef]

Náñez Alonso, Sergio Luis. 2019. Activities and operations with cryptocurrencies and their taxation implications: The spanish case. Laws 8: 16. [CrossRef]

Náñez Alonso, Sergio Luis, Miguel Ángel Echarte Fernández, David Sanz Bas, and Jarosław Kaczmarek. 2020a. Reasons Fostering or Discouraging the Implementation of Central Bank-Backed Digital Currency: A Review. Economies 8: 41. [CrossRef]

Náñez Alonso, Sergio Luis, Javier Jorge-Vazquez, and Ricardo Francisco Reier Forradellas. 2020b. Detection of Financial Inclusion Vulnerable Rural Areas through an Access to Cash Index: Solutions Based on the Pharmacy Network and a CBDC. Evidence Based on Ávila (Spain). Sustainability 12: 7480. [CrossRef]

Náñez Alonso, Sergio Luis, Javier Jorge-Vázquez, Miguel Ángel Echarte Fernández, and Ricardo Francisco Reier Forradellas. 2021a. Cryptocurrency mining from an economic and environmental perspective. Analysis of the most and least sustainable countries. Energies 14: 4254. [CrossRef]

Náñez Alonso, Sergio Luis, Javier Jorge-Vazquez, and Ricardo Francisco Reier Forradellas. 2021b. Central banks digital currency: Detection of optimal countries for the implementation of a CBDC and the implication for payment industry open innovation. Journal of Open Innovation: Technology, Market, and Complexity 7: 72. [CrossRef]

Nidhiprabha, Bhanupong. 2016. Impacts of quantitative monetary easing policy in the united states and japan on the thai economy. The Developing Economies 54: 80-102. [CrossRef]

Nosratabadi, Saeed, Amirhosein Mosavi, Puhong Duan, Pedram Ghamisi, Ferdinand Filip, Shahab S. Band, Uwe Reuter, Joao Gama, and Amir H. Gandomi. 2020. Data science in economics: Comprehensive review of advanced machine learning and deep learning methods. Mathematics 8: 1799. [CrossRef]

Obinabo, Chinyere Rose. 2017. Cashless economic policy: An analysis of financial intermediation in the pre and post cashless policy periods. Journal of Policy and Development Studies 11: 1-12. [CrossRef] 
Ojo D Delaney, M. 2020. Monetary and economic policy impacts of the COVID-19 pandemic in the United Kingdom. SSRN Electronic Journal. [CrossRef]

Okano, Eiji, and Masataka Eguchi. 2020. The importance of default risk awareness in conducting monetary and fiscal policies. Eurasian Economic Review 10: 361-92. [CrossRef]

Ortiz Zarco, Ruth, and Ignacio Perrotini Hernández. 2019. Asimetría y convergencia en política monetaria entre Canadá, Estados Unidos y México. Economía: Teoría Y Práctica, 105-33. [CrossRef]

Parella, Jordi Franch. 2018. Unconventional expansionary monetary policies. An economic analysis of quantitative easing. Journal of Business E Economic Policy 5: 22-28. [CrossRef]

Parra Barrios, Alberto. 2019. Impacto de las decisiones de política monetaria de la FED en indicadores de la economía colombiana durante el período de 2007 a 2015. Revista Finanzas Y Política Económica 11: 149-82. [CrossRef]

Perović, Malesevic Lena. 2015. Investigating croatian inflation through the cointegration with structural break approach. Journal of Economic and Social Studies 5: 221-34. [CrossRef]

Reier Forradellas, Ricardo Francisco, Sergio Luis Náñez Alonso, Javier Jorge-Vazquez, and Marcela Laura Rodriguez. 2021. Applied machine learning in Social Sciences: Neural network and crime prediction. Social Sciences 10: 4. [CrossRef]

Rogoff, Kenneth. 2017. Monetary policy in a low interest rate world. Journal of Policy Modeling 39: 673-79. [CrossRef]

Rutter, Harry, Miranda Wolpert, and Trisha Greenhalgh. 2020. Managing uncertainty in the COVID-19 era. BMJ $2020:$ m3349. [CrossRef]

Sambira, Jocelyne. 2014. Hunting for eurobonds. Africa Renewal 28: 30-32. [CrossRef]

Sampieri, Roberto Hernández. 2018. Metodología de la Investigación: Las Rutas Cuantitativa, Cualitativa Y Mixta. New York: McGraw Hill

Sanz Bas, David. 2020. Hayek and the cryptocurrency revolution. Iberian Journal of the History of Economic Thought 7: 15-28. [CrossRef]

Sanz Bas, David, Carlos del Rosal, Sergio Luis Náñez Alonso, and Miguel Ángel Echarte Fernández. 2021. Cryptocurrencies and fraudulent transactions: Risks, practices, and legislation for their prevention in Europe and Spain. Laws 10: 57. [CrossRef]

Solís, Mireya, and Shujiro Urata. 2018. Abenomics and japan's trade policy in a new era. Asian Economic Policy Review 13: 106-23. [CrossRef]

Suárez Ibujés, and Mario Orlando. 2011. Coeficiente De Correlación De Karl Pearson. December 9. From Repositorio Digital Universidad Técnica del Norte Website. Available online: http:/ / repositorio.utn.edu.ec/handle/123456789/766 (accessed on 24 January 2021).

Suárez Ibujés, and Mario Orlando. 2018. Probabilidades Y Estadística Empleando Las TIC. June 13. From Repositorio Digital Universidad Técnica del Norte Website. Available online: http:/ / repositorio.utn.edu.ec/handle/123456789/8698 (accessed on 24 January 2021).

Switzer, Lorne Nelson, and Alan Picard. 2016. Stock market liquidity and economic cycles: A non-linear approach. Economic Modelling 57: 106-19. [CrossRef]

Tercero-Lucas, David. 2021. Nonstandard monetary policies and bank profitability: The case of Spain. International Journal of Finance E Economics. [CrossRef]

Wang, Olivier. 2018. Banks, low interest rates, and monetary policy transmission. SSRN Electronic Journal. [CrossRef]

Wang, William, and Antonio Vegas García. 2020. Business cycle and stability of China's financial and monetary system. Revista Procesos de Mercado 14: 123-71. [CrossRef]

Wang, William Hongsong, Vicente Moreno-Casas, and Jesús Huerta de Soto. 2021. A free-market environmentalist transition toward renewable energy: The cases of Germany, Denmark, and the United Kingdom. Energies 14: 4659. [CrossRef]

Xing, Yuqing. 2020. Japan's Practice of Modern Monetary Theory amid the Pandemic Recession. East Asian Policy 12: 47-56. [CrossRef] 